\title{
Existential transformations in the process of facing amyotrophic lateral sclerosis by the family caregiver
}

\author{
Transformações existenciais no processo de enfrentamento da \\ esclerose lateral amiotrófica pelo cuidador familiar \\ Transformaciones existenciales en el proceso de enfrentamiento de la \\ esclerosis lateral amiotrofica por parte del cuidador familiar
}

\author{
Lays Pedrosa dos Santos Costa \\ Isabel Comassetto ${ }^{a}$ \\ Regina Maria dos Santos ${ }^{\mathrm{a}}$ \\ Amuzza Aylla Pereira dos Santos ${ }^{a}$ \\ Guilherme Oliveira de Albuquerque Malta ${ }^{a}$ \\ Karine de Melo Cezar Alves ${ }^{\mathrm{a}}$
}

How to cite this article: Costa LPS, Comassetto I, Santos RM, Santos AAP, Malta GOA, Alves KMC. Existential transformations in the process of facing amyotrophic lateral sclerosis by the family caregiver. Rev Gaúcha Enferm. 2021;42:e20200307. doi: https://doi. org/10.1590/1983-1447.2021.20200307
Universidade Federal de Alagoas (UFAL), Escola de Enfermagem. Maceió, Alagoas, Brasil.

\section{ABSTRACT}

Objective: To understand the existential transformations of the family caregiver of a person living with Amyotrophic Lateral Sclerosis. Method: Qualitative study based on assumptions of Martin Heidegger Existential Phenomenology, with 12 family caregivers of the person with Amyotrophic Lateral Sclerosis, in Alagoas. The testimonies were obtained from June 2019 to March 2020 and analyzed, categorized, and discussed based on the theoretical-philosophical framework adopted and thematic literature.

Results: Phenomenological sense of the existential transformations of the family caregiver of a person living with Amyotrophic Lateral Sclerosis, unveiled with the categories: Being the caregiver of the person living with ALS; Being responsible for decision making; Resignifying the existence in view of the possibility of loss; Spirituality influencing the transformation process.

Conclusions: The family caregiver has an appropriate life due to the inherent vicissitudes of the disease, which provides moving moments that lead him to rethink his existence and to value life.

Keywords: Nursing. Qualitative research. Amyotrophic lateral sclerosis. Caregivers.

\section{RESUMO}

Objetivo: Compreender as transformações existenciais do cuidador familiar de uma pessoa que vive com Esclerose Lateral Amiotrófica. Método: Estudo qualitativo fundamentado em pressupostos da Fenomenologia Existencial de Martin Heidegger, com 12 familiares cuidadores da pessoa com Esclerose Lateral Amiotrófica, em Alagoas. Os depoimentos foram obtidos de junho de 2019 a março de 2020 e analisados, categorizados e discutidos a partir do referencial teórico-filosófico adotado e literatura temática.

Resultados: Sentido fenomenológico das transformaç̧̃es existenciais do cuidador familiar de uma pessoa que vive com Esclerose Lateral Amiotrófica, desvelado com as categorias: Sendo cuidador da pessoa que vive com a ELA; sendo responsável pela tomada de decisão; Ressignificando a existência diante da possibilidade da perda; A espiritualidade influenciando o processo da transformação. Conclusões: 0 familiar cuidador tem sua vida apropriada pelas vicissitudes inerentes à doença, que proporciona momentos comoventes que o leva a repensar sua existência e valorizar a vida.

Palavras-chave: Enfermagem. Pesquisa qualitativa. Esclerose amiotrófica lateral. Cuidadores.

\section{RESUMEN}

Objetivo: Comprender las transformaciones existenciales del cuidador familiar de una persona que vive con Esclerosis Lateral Amiotrófica.

Método: Martin Heidegger, con 12 cuidadores familiares de la persona con Esclerosis Lateral Amiotrófico, en Alagoas. Los testimonios se obtuvieron de junio de 2019 a marzo de 2020 y analizados, categorizados y discutidos con base en el marco teórico-filosófico adoptado y literatura temática.

Resultados: Sentido fenomenológico de las transformaciones existenciales del cuidador familiar de una persona viviendo con Esclerosis Lateral Amiotrófica, develado con las categorías: Ser el cuidador de la persona que vive con ELA; Ser responsable de la toma de decisiones; Redefinir la existencia ante la posibilidad de pérdida; La espiritualidad influye em el proceso de transformación. Conclusiones: El cuidador familiar tiene una vida adecuada debido a las vicisitudes inherentes a la enfermedad, lo que le brinda momentos conmovedores que lo llevan a repensar su existencia y valorar la vida.

Palabras clave: Enfermería. Investigación cualitativa. Esclerosis amiotrófica lateral. Cuidadores. 


\section{口INTRODUCTION}

Among the range of Motor Neuron Diseases (MND), Amyotrophic Lateral Sclerosis (ALS) configures as one of the most frequent being characterized by the involvement and combined degeneration of upper and lower motor neurons. Thus, it is a pathology classified as progressive degenerative neuromuscular due to irreversible changes in the cells of the motor neurons in the brain stem, as well as in the spinal cord and spinal and bulbar pathways, responsible for controlling voluntary movements ${ }^{(1)}$. With the evolution of the degenerative process of the disease, the affected person presents increasing difficulty to perform basic activities such as walking, eating, talking and breathing, reaching to be totally paralyzed ${ }^{(2)}$.

In this context, the family caregiver is characterized as a person who assists and cares for a family member who lives with some type of disease, disability or handicap that may hinder the performance of their activities of daily living, their insertion and social role and functionality, establishing even unconsciously a relationship of dependence that causes them to intimately experience the disease of their relative.

In this study, the definition that supports the concept of family constituted as a privileged place for the production of meanings and practices associated with health, disease and care was adopted, a place that, in contemporary times, is dynamic and its constitution is flexible in form and organization being able to expand to neighborhood and kinship ${ }^{(3)}$. Therefore, for the conduct of the present research, the following concept was chosen about the family institution: The family is a space of care that is naturally recognized and confirmed by the responsibilities that its members attribute to it. It is in the family that the first care is observed, which allows the individual not only to develop their biological body, but also their social insertion, the transmission of culture and socialization ${ }^{(4)}$.

Family caregivers, when involved in the intense routine of caring for a fully dependent person, find an incessant, repetitive and exhausting practice ${ }^{(5)}$. A terminal disease is defined as one that does not have specific curative treatment or that has the capacity to delay evolution and, therefore, leads to death in a variable time, is progressive, causes intense, multifactorial, changeable symptoms and implies great physical and psychic suffering in the family and in the patient ${ }^{(6)}$.

Compulsory enrollment to assume the role of care, lack of preparation and support and loss of control have an impact on the safety of family caregivers. In addition, psychological and physical health deficiencies and financial problems create a safety concern for caregivers ${ }^{(7)}$. Thus, the family needs to overcome the barriers imposed at each moment and elect a primary caregiver.

In the scope of palliative care, the family is an important element to participate, in addition to patient care, in decision-making and emotional and structural support. Family caregivers receive care demands and may interrupt their way of life and present changes in their physical and mental health, relationships, finances, increased risk of secondary morbidity due to anxiety and depression. Some authors also express that the timely monitoring of family members increases the likelihood of significantly positive results for caregivers and people affected by diseases ${ }^{(6)}$.

Therefore, caregivers end up continuously experiencing conflicting feelings, facing different tasks, never performed before and that require physical, psychological, social, intellectual and financial resources, which they often do not have. Then, some contradictory feelings emerge, such as love and hate, joy and suffering, euphoria and depression, acceptance and rejection ${ }^{(8)}$.

It is observed that, as the disease progresses and the end of life is perceived, the people responsible for providing care need to make changes and restructure their lives so that it is possible to adapt to a new reality of insertion in the world, which supports a process of construction of new meanings, representations and postures ${ }^{(9)}$. Resignification is a process of subjectification by which the person appropriates his condition, an act that causes a reorganization, changes and a new conception of life for that is able to situate itself in the current existential context caused by the disease.

It is in this existential space that the person is visited and revisited due to the restlessness caused by a new living situation. The perception and appropriation of this reality, interpenetrated by significant fields of affective-existential sense, help to redefine and continually reorganize its horizon of meaning, vital sense. The process of re-signifying life in the face of disease situation is understood as the ability to modify the mold by which a person perceives events, in order to change their meaning. When the meaning changes, the person's responses and behaviors change concomitantly ${ }^{(10)}$.

In view of the above, the question that guided the study was: What are the existential transformations of a family caregiver of a person living with ALS? This questioning was established with the intention of reaching the proposed objective, which consists of understanding the existential transformations of the family caregiver of a person living with Amyotrophic Lateral Sclerosis.

In view of the factors related to the need for advancement with regard to the thematic, the importance of 
deepening the discussion on the relational and existential issues involved in this care relationship and the need to advance in research is emphasized. Above all, with regard to the impacts of the disease on the lives of those affected by it, whether directly or indirectly, a view that tends to generate strong bases for doing so in the healthcare practice of health professionals involved in the context of the disease.

\section{$\square$ METHOD}

It is a qualitative research of descriptive type with an approach to Heideggerian existential phenomenology. This methodology enabled the understanding of the experience lived by family caregivers who accompanied the person affected by ALS, considering them in their singularities and allowing a close relationship with a wide range of meanings, feelings, interpretations, actions and human relationships, which configured a type of study that deals with the magnitude of the phenomena in the search for the existential totality. Heideggerian phenomenology brings within it the question of Being as an intrinsic human issue ${ }^{(11)}$.

This research is part of a dissertation ${ }^{(12)}$, developed with family caregivers of people with ALS, attended by the Health Department (SESAU), in pharmaceutical assistance, from the State of Alagoas, registered to receive the drug Riluzol.

Forty-one records of people with ALS were found at SESAU. After investigation by telephone contact, it was concluded that: 12 did not have an updated contact number; four died; five denied having a diagnosis of ALS; eight relatives of the person with ALS did not accept to participate in the research and 12 participated in the research.

For the choice of the participating family member, the following inclusion criteria were used: being a family caregiver of a person with ALS, who is alive; Over the age of 18 years; To be the closest family member of the person with ALS and who had been experiencing the illness process. Family caregivers who did not have minimal cognitive conditions, such as changes in language, memory, lucidity and sense of perception, which would make it impossible to establish a dialogue about their experience, were excluded.

After the participants were identified and invited, the meetings for the phenomenological interviews were scheduled according to the availability and location preference of each participant. The testimonies were collected between July 2019 and March 2020. Each participant was interviewed only once. The experiences of family caregivers of ALS patients constituted the region of investigation of this study, that is, a conceptual space in which the phenomenon to be unveiled is situated.

All participants chose their own residence to conduct the interviews, where they provided a private environment. The Free and Informed Consent Term (ICF) was read and signed in order to prove their agreement with the completion of the study. At the time of the interview, which were all carried out by the same researchers, the rules of confidentiality, anonymity and permission to record the testimony on an MP3 player were reiterated and the non-verbal manifestos of the participants were noted in a field diary.

For the interviews, which lasted an average of one hour and twenty-five minutes, an instrument was used, containing pertinent questions to the sociodemographic data, followed by the triggering question: Tell me, how is the experience for you of being the family caregiver of a person living with ALS?

The analysis of the testimonies was carried out by the same researchers who conducted the interview, concomitantly with the collection of the testimonies, each interview was fully transcribed, and the discourses were organized, with a view to making feasible the meanings attributed to their experiences.

Following Heidegger's comprehensive methodical moments, the first interpretive movement was carried out, also called vague and median understanding, whereby the immediate instance of the lived was revealed, from where the meanings shown in the discourses of the interviewees were apprehended. At this moment, what has emerged directly shows the optical primacy or optical meanings, from which the units of meaning emerge. It is also a movement that involves the process of detaching assumptions, concepts and beliefs that can intervene in the interpretation of the findings. In the second analytical movement, it was sought to unveil the meaning hidden in appearances, called ontological revelations, reaching the phenomenological sense. The results were discussed based on the assumptions of Heidegger's existential phenomenology and thematic framework.

Resolutions 466/12 and 510/16 and the Operational Norm 001/2013 of the National Health Council (CNS) were respected, with approval by the Ethics Committee in Research with Human Beings of the Universidade Federal de Alagoas (UFAL), under the statement 3.183.044. CAAE: 063395180.0.0000.5013. Participants were identified by the letter " $\mathrm{P}$ " referring to participants, followed by the ordinal number, according to the sequence of the interviews. 


\section{RESULTS AND DISCUSSION}

Twelve family caregivers participated in the research, 11 women and one man, aged between 18 and 71 years old. From these, 11 were married or living in a stable relationship and one was divorced. As for the level of schooling, it was evidenced that six had completed high school, three had higher education degrees, two were illiterate and one had elementary education. Catholicism was the prevalent religion with six participants, four were evangelicals and two agnostics. Regarding the kinship degree with the person with ALS, four were daughters, three were spouses, two were sisters, one was a father, one sister-in-law and an affinity relative. From these, nine reside in the capital and three reside in the interior of the state.

The testimonies analysis allowed to reveal the Phenomenological sense of the existential transformations of the family caregiver of a person living with Amyotrophic Lateral Sclerosis

The existential transformations of the family member, resulting from the process of coping with ALS was based on the being-there that is manifested through the presence as a caregiver, in order to perceive its ontological dimension when exercising the purpose of its existence in the interrelation with the world-of-ALS, a rare disease that leads family caregivers to launch themselves, driven by love for their loved one, to be-in-the-world-of-ALS. According to the categories described:

\section{Being the caregiver of the person living with ALS}

In view of the authenticity, the family caregiver assumed its existence, taking for himself the attitude of being aware of the possibility of dedicating himself to provide an end of life permeated by tender and affection for his family member, as the estimated time of life was short. Thus, there was an appreciation of care with the understanding advocated by Heideggerian phenomenology, that care contemplates the positive way of caring for your loved one, understanding that it is important and not as a synonym for kindness.

For the family caregiver, this care occupied an ontic sense, which went beyond the act and assumed a sense, driven by love, he understood that caring with love made his legacy a mutual exchange, understood in the valorization of Being, giving meaning to the life of both.

The essential thing is love to take care of a person. So, everyone who has a relative, a loved one, who takes care without aiming at anything in return. Do it for love. I learned, grew, matured and am what l am today because of her. She never let me give up anything, she always gave mestrength [...], I thank the Lord for her life and my health so that I can do all this. [...]. Since there is no cure so far, I hope she is as happy as possible. [..., it is not to feel sorry, but to take care with love and do everything in reach. $(P 2)$

From a Heideggerian perspective, only love is the power that makes possible to be and become the possibility capable of being, it is what makes it prosper. The family caregiver, by clinging to being-with-ALS in its essence, made the relationship of being-with possible, because love is what it lets-be. The basis of care was the possibility of the relationship between the family caregiver and the person with ALS.

Authenticity leads to the affective bond created throughout life and maintained these relationships that were built under solid and true affective pillars, unshakable, even in the face of fatality, being interpreted as inevitable in an inexorable and unavoidable process ${ }^{(11)}$.

I tell her that her family is us, the daughters. The rest don't even ask how she's doing. Imagine making a visit! (P10)

In the face of adversity, family caregivers expected support from other family members, however, they felt abandoned along with the person with ALS. This unavailability was independent of the degree of kinship and the withdrawal occurred under different pretexts, making the experience of the final process of life permeated by the feeling of family abandonment, which provided depressive moments for the person with ALS and the family caregivers who experienced the pain of being frustrated with the behavior of the family itself:

She has eleven children and another grandson she raised since she was a child and today only three are involved in the care. All the others, on the other hand, left with the excuse that they do not like seeing their mother like this and in this distance that occurred mainly after the start of Home Care, because they thought they were no longer obliged [...] she got worse. [...]. Sometimes I notice the poor thing with fear, many times she doesn't even sleep because she is anguished thinking that can't even speaking to ask for help, help even to move. Then, forme, that Iface, it is such a pain! Today it is being very difficult for me and for her, [.... (P1) 
She has this daughter who lives here together and more three children, who unfortunately were no longer close and moved away even more after the illness [...]. (P2)

Relatives close to ALS patients were overwhelmed with the challenges of daily life, although some had the support of specialized caregivers. However, diverse responsibilities, concerns about the end of life and the end of treatment have become part of everyday life, making the closest family members feel trapped at home and intimately involved until the end ${ }^{(12)}$.

Current public policies tend to transfer the care of ALS patients to outpatient and home care, with a view to reducing expendable interventions, as well as the hospital costs resulting from long hospitalizations and more invasive interventions performed in a hospital environment. In this context, the family may suffer from the diagnosis and evolution of the clinical manifestation of the disease, which encompasses everything that permeates the experience of this progressive and degenerative disease ${ }^{(13)}$. Given the burden that is placed on the caregiver, there is a negative impact affecting their mental and physical health, due to the scenario that is configured of caregivers, humans, vulnerable struggling day after day to maintain control of all aspects that permeate the lived ${ }^{(14)}$.

\section{Being responsible for decision making}

Another aspect inherent in being a family caregiver of a person with ALS was the task of, as a consequence of the evolution of the disease's degenerative process, having to make decisions together with the ALS carrier or, at sometimes, even making decisions for him:

I often become quieter, [...] in decisions we collapse, because I am the one who goes with her to the hospital and I see everything she goes through, each procedure,

I see the pain [...] so, the experience is very painful. (P10)

Considering the difficult context of life in which was the being-with-ALS, there was hesitation when there was a need to choose procedures or treatments that would not provide a cure, but only the prolongation of the suffering days of that being. The preservation of consciousness and cognitive functions allows the person with ALS to watch the process to the fullest extent of their faculties and abilities, even if limited to participate in decision-making and express desires, criteria and opinions ${ }^{(15)}$.

The family member who assumed the role of caregiver showed awareness of the situation established with the disease in his loved one, when experiencing his pain struggles to alleviate it, he felt frustrated when he realized that the other family members did not perceive in the same way. The family caregiver remained close, aware that his loved one was living in a body weakened by the disease and felt the pain that accompanied him throughout the process of the end of life:

Some of the sons do not want anything to be invested. Right now, when I fought to get the coughing machine, they kept asking me what the need for it was, since she will die anyway. And I said yes, that she will die, but she doesn't have to be suffocated, full of secretion. (P1)

The phenomenon of fear of the future can be considered under three perspectives: what is feared; what to fear and for what to fear. What is feared, the fearsome, is always an entity that comes into the world and is simply given. You do not see a future evil (malum futurum) first and then feel afraid. It is by being afraid that you can be clear about yourself, what to be afraid of. Only the Ent in which, is at stake, his own being, can be frightened. When fear is linked to the event of death, even if it is intrinsic, existence creates in the close relative a feeling of uncertainty about the unknown and the future ${ }^{(16)}$.

This fear that permeated the existence of the family caregiver who suffered with the evolution of the disease, because he/she knew the difficulties that his loved one would go through, and with that, he/she is available to be together in each difficult stage, at the time when he/she asks for serenity to enter the world-of-ALS, because it will remain in it until the final moment. This initial empathy will tend to mitigate the impacts that will be accumulated in the course of the experiences that will arise:

Welearn to love people when we feel in the skin like they are [...]. Sometimes I see the Home Care people who take care of her complaining and I just ask that each one put themselves in her place, that they imagine that they are lying there in that bed, that it is their mother [...] you would think it is good? (P2)

Empathy is considered the basis of effective communication and one of the most important skills that human beings have the capacity to develop. It reveals itself as the ability to put oneself in the place of people, so that they can visualize and feel in the same perspective the experiences lived by another, a fundamental attitude for the physical and mental well-being of both ${ }^{(17)}$. 


\section{Resignifying the existence in view of the possibility of loss}

The ALS frightened the carrier, who witnessed his life disappearing, while the family caregiver witnessed the disease stealing his loved one, remaining immersed in intense suffering:

It is difficult because we see him well and overnight see himself ending up like that, this manner. [...] sometimes l avoid going so to not see his suffering. Sometimes l am there and I see that he is standing in front of the mirror looking at himself, he lowers his head and leaves [...] I just watch from afar and it tears me up inside. It is a lot of suffering! (P4)

One of the strategies used by family caregivers who experienced this process was not to anticipate the suffering of the loss, not to focus on the next events, to live one day at a time, seeking to meet the demands at the moment they arise, which was perceived as a way to uncomplicate and mitigate the suffering inherent to the experienced process:

I don't really like to go deeper, actually. I try to go more slowly, [...] if we are going to anticipate, it is even more painful. I always think: [...] has that time come? If it hasn't arrived yet, I'll leave it alone. [...]. I don't suffer in anticipation (P6).

Now I even stopped, but when I learned more about the diagnosis, I knew that she was going to need a tracheostomy, a gastrostomy [...] about the evolution. But nowadays I don't care so much. I live day after day. We learned to deal with each stage. It was not easy, but it was always like that (P10).

The family caregiver opted to gradually enter the worldof-ALS, demonstrating awareness of its evolution, without anticipating stages that would bring suffering in the future. In the chronic disease, a high level of uncertainty is common to family caregivers, before and in the progress of the disease and with an increase in the proximity of finitude ${ }^{(9)}$.

Thus, the world-of-ALS was not restricted to the disease's carrier, as their family members accompanied and experienced their devastating progress and, in view of this circumstance, the family caregiver persisted in enabling comfort through small attitudes that were within their reach:

Sometimes she is unable to breathe, this is the worst for me. She rings the alarm and I run all the way to go and defend her. (P8)
[...] there was a night when she went to sleep in agony for not being able to speak and then my husband had the idea to put a bell in her room. (P9)

The prevailing feeling in the family caregiver was the weight of feeling immersed in a world made up of problems and difficulties, he realized surrounded by worries and loads that were the result of the sum of those that came from his own life and those that resulted from the lived world-ofALS, that, when taking care of themselves, felt responsible for leading the adversities that arose, which could result in their becoming ill. For, the world-of-ALS is more frightening than the world-of-cancer that has treatment and possible cure, but in the face of the fight against ALS they felt emotionally shaken. Family members often felt vulnerable and traumatized, due to the numerous tasks and concerns, they felt powerless and desperate, and seemed unable to find solutions to live a normal life ${ }^{(14)}$.

I already do the treatment for breast cancer [...] she got sick and as everyone left, there was only me left to take the lead. But if we are not careful, we get sick together and get sick badly. Because / realize that I am unbearable. [...] and look that I went through cancer, which I thought was the worst disease, but today I see that this one is much worse. (P1)

In addition, over the years, the family members of ALS carriers have experienced increasing difficulties in relation to their life. The family members felt neglected and the attention was turned only to the carrier of the disease, they felt helpless in listening to their frustrations and they did not feel they recognized their effort ${ }^{(14)}$.

Then this disease is killing her, as well as killing those around her, [...] it is a lesson in life. (P2)

The world-of-ALS involves the family caregiver at its core, reaching more deeply those closer, who maintain an emotional and affective connection with the ALS. Because, this person tends to underestimate his needs and becomes a "hidden sick":

We suffer together [...] we realize that we are no longer able to cope. Today I see that Ilive because of him, because I just go out to work and study and when I go anywhere else, I take him. I no longer have a social life. I can't go out alone, I don't think it's fair to him [...]. (P3)

Is very difficult. [...] I often cry, when he can sleep I take the opportunity to cry. But there are many nights when he 
can't sleep and he spends the whole night asking me to turn him over [...]. Neither I sleep nor he sleeps. The next day, we are both headaches, unwell. (P5)

The ALS arrived suddenly, without giving time for acceptance and quickly shook the physical structure of the carrier, leading him to suffer as he settled in, during this process he reached everyone in his life. The family caregiver perceives his life permeated by the disease, whereas the person with ALS, in turn, needed uninterrupted care, making the life of this relative very exhausting:

The profound experience of this disease is that you live his disease, you get stuck with him. He is stuck in his illness and you are stuck in his illness. Everyone passed, but whoever lives with him, [...] gets sick together. (P6)

Suffering involved the development of this difficult role, but although extremely arduous, it became preferable to the end of being with the person with ALS, since this implies the definitive loss of the loved one.

For some family caregivers, the way the person with ALS is able to reframe their life and persist in living the life that is presented is a reason for admiration and pride. When faced with a family member with ALS who does not let himself be overwhelmed by the death envelope that permeates the world-of-ALS, it refers to a rethinking of the existentiality of being and the extraction of teachings and the meaning of this relationship.

The good thing is that he has a very good head, because you live your whole life working and suddenly you see your life stop like that [...] I admire him a lot, because for a lot less I seepeople getting depressed and he managed to cope well with the diagnosis. (P3)

For me it was a teaching, I learned a lot personally because he is in that situation, buthe doesn't stop studying, he still takes courses on the computer. He has no limits, no regrets. He accepts, but has faith that there will be a cure [...]. (P12)

It is observed, then, that as the disease progresses and the end of life is perceived, the people responsible for providing care need to make changes and restructure their lives so that they can adapt to a new reality of insertion in the world, which supports a process of building new meanings, representations and attitudes ${ }^{(9)}$.

It was revealed that the family member who lives with the being in the world-with-ALS remains aware that time is primordial, since their loved one has been given a life span or a death sentence with a pre-established period of time, permeated by the tearing progress of the disease, which will result in complete disability, degeneration and, inevitably, death.

I know that this moment will come and I know that she will not reach that moment when there will be a less suffered treatment, with better answers, unfortunately. The cure, I believe that one day will come, but we know that it is something that is still far away, she will not achieve. (P1)

My warrior! For ten years beating this disease every day. (P2)

The research aroused the encouragement and transmitted support to those who experience ALS, since the low visibility that accompanies the disease leads them to a disturbing stage of gloom. Thus, conducting research in this context tends to bring the subject to light and lead to high-value advances, as emphasized participant nine (P9), who expresses the idea that the relative sees the research as a way to fight against ALS, always being available to collaborate in this confrontation.

Every research that invites me to participatel always say that I am in, I make a point of participating. Any advance is welcome for our situation. (P9)

The family caregiver admitted that ALS is difficult to face and that the presence of researchers who give attention is very important, as he is aware of the difficulty of finding a cure, but maintains the hope that it will be achieved.

\section{This is a lesson from God that I will take for the rest of my life. llearned to live, appreciate and love people through it. Every day a difficulty, a different thing, we need to kill a lion to survive. But we are winning every day, I just don't get used to seeing her suffering. All I wanted was for there to be a cure. [...] (P2)}

Aware of promising treatment for other diseases that have already been fatal, family members also have the hope that some treatment will find a cure for ALS. They demonstrated to know that researchers dedicate their lives in the search for this cure. The family members of ALS patients accompany each advance that is made in this direction and value the team that is dedicated to keeping your loved one with a slow evolution of the disease, praising each gesture of effort. 
Nowadays you live with HIV, with cancer and we don't count on that. People living with this disease do not have that hope. He has the hope that the cure will exist and he will be fine. He believes and I think that's what keeps him alive. [...] We try to at least keep him alive until something new comes up and we go on living each day, feeding our hope. (P3)

The awareness of the family caregiver was evident that the cure is still a utopia and what remains at the moment is a period of suffering, but it has treatments that can act in order to alleviate the suffering a little.

\section{Spirituality influencing the transformation process}

Among the strategies that were used to obtain strength, both to deal with the incomplete evolution of the disease and with the arduous mission of being a family caregiver of the person with $A L S$, the spirituality involved the imminence of the loss process. As well as the need to adapt to a new reality in life, which included the addition of limitations of basic functions that fleetingly impact the routine and habits.

Spirituality helped to relieve the daily burden of stress for family caregivers. Through potential mechanisms of feeling the presence of a greater power, being a dimension of transcendence, spirituality can be lived either in a religious environment or an individualized experience ${ }^{(18)}$.

In this context, motivation and comfort allowed us to believe that things would unfold in the best possible way. Spirituality can be used as a way to encourage hope for healing and restructuration of life during treatment ${ }^{(19)}$. The possible benefits of religious beliefs, in some situations experienced, in which there was an explicit possibility of death, were the relief of fear and uncertainty and emotional comfort:

Faith and spirituality are very important, in the beginning, Mom had the hope of getting well, of the miracle, and she was still talking, still moving her fingers. In this, her faith diminished and on a daily basis, we know that if we do not feed on that faith, we will lose. This is very important, we cannot live without a meaning in life. (P1)

[...] we know how good it can only be if God heals and, above all, our faith goes over all things and we know that he will only be good if it is the will of God [...]. (P3)

Only God to provide a cure for him, because nothing for God is impossible. (P4)

Trust in divine power, that is, in faith and trust in God, manifests itself as an instrument used to face this disease ${ }^{(16)}$.
The faith in the possible cure persisted even in the face of scientific data, but with the rapid evolution of ALS, that faith was waning, which made life more difficult. The wisdom about the prognosis of ALS and the lack of treatment leading to a cure, strengthened the attachment to faith as the only alternative. In the world-of-ALS, spirituality, sustained by faith in God, served as support to give strength and serenity to live facing the final process of life:

I talk so much that he has to believe, have faith, think about God, talk to God. I tell him to pray with the thought when he sleeps, when he gets up, since with his hands he can no longer. [...] God will give me strength, courage and patience to take care of him for the rest of my life and I have faith in God that he will be well, be healed. (P5)

Religiosity was used as a way to encourage hope for healing and restructuring of life during treatment. Religious support is presented as an inverse association with uncertainties, which the disease causes in caregivers'lives, showing the importance of religious environments for family support at the end of life ${ }^{(9)}$. Fearing for, is another Heideggerian conception where you can be afraid instead of another, which makes you fear also with the other, not removing your own fear. Most of the time, we fear in place of the other just when he is not afraid and faces what threatens him. This is not about degrees of feeling, but in existential ways ${ }^{(11)}$.

The strength to endure the adversities that involve the world-of-ALS comes from a supreme force, a divine entity, and through faith those involved sought ways to live with the disease and live their final moments in peace. Every victory in the fight against ALS was attributed to God, they believed that spiritual strength would be capable of the impossible.

\section{[...] religion was essential in this acceptance process. (P6) \\ [...] if he leaves, I will be calm because he will be with God and otherwise, I will tell you about our miracle! (P7) \\ I always believe that for God nothing is impossible and so I take it. (P10)}

People with neurodegenerative diseases and their families tend to incite treatments with spirituality, beliefs and religious practices, using them as an artifice in order to alleviate the ills of everyday life and also to maintain the hope, meaning and purpose in life that remedies do not solve ${ }^{(20)}$. That is, the longing for a cure was transferred from a drug or treatment, as occurs commonly in other diseases, to the faith, almost exclusively. 
My pastor came home this week and said that God had that purpose in our lives. [...]. (P7)

Attached to the faith they remain in the fight against ALS, when time appears as a determining factor because it is an incurable disease, time is attributed to the race that is waged to maintain a new life condition and the expectation for discovery of cure.

After going through the entire trajectory unveiled in the midst of the target phenomenon of this study, about the experiences of people who care for beings affected by ALS, seeking to understand them through the experience of the family caregiver, it was noticed that a significant part of the situations reported here are ruthlessly imposed on these people exclusively because of the diagnosis they carry, even if indirectly, since the participants in this study are not ALS carriers, but those who actively participated in this disease process.

It is explicit the difficulty expressed in all the reports of family caregivers, which revealed the perpetuation of the suffering that surrounds this condition, from its discovery to its understanding. In this context, the main way of coping explored was the mainstay of empathy, faith and hope deposited in the expectation for better and more prosperous days, based on a new meaning of ways of living-with-ALS, caring for and watching over for your loved one.

\section{$\square$ CONCLUSIONS}

This study aimed to reveal the existential transformations resulting from the process of facing ALS by the family caregiver. Thus, it can be considered that the results presented achieved the proposed objective. Although each family caregiver has their loved one experiencing different stages of ALS, all participants contributed to the unveiling of the phenomenon hidden in the lived experience.

Commonly, the fullness contained in the testimonies of the lived experience, for which the veiled emerged, stands out. There was an expressive care for his loved one, permeated with love and dedication, throughout the process of facing with ALS, with emphasis on attachment, spirituality and empathy. Faced with a disease with progressive loss and no prognosis for a cure, the family caregiver perceived himself as being susceptible to death and began to value his life and that of his loved one.

From this study, it is possible for nursing to envision care directed to family members who care for their loved one with terminal illness, guided by the lived experience of being-caregiver-family, care that occurs permeated by subjectivity and intersubjectivity, concretized by a being who cares.

It is considered as a limitation of this study, the absence of sociodemographic data on ALS patients, as it is not a disease of compulsory notification by the public service, the information that would allow reaching a larger number of participants is difficult to track. In addition, there is variation in the profile of people affected by ALS, cared for by the interviewees in this study, with regard to the time to receive the diagnosis and stage of the disease's evolution, which interferes in the experience lived by the family caregiver. Therefore, the importance of continuing future research on the topic is emphasized, given that there are several points that deserve an exploration. The survey of the epidemiological profile of this group and a mapping focused on cases of familial ALS, for example, are possible studies that will bring a broader and more consolidated understanding about the theme.

\section{REFERENCES}

1. Gozzer MM, Cola PC, Onofri SMM, Merola BN, Silva RG. Fiberoptic endoscopic findings of oropharyngeal swallowing of different food consistencies in Amyotrophic Lateral Sclerosis. CoDAS. 2020;32(1):e20180216. doi: http://doi. org/10.1590/2317-1782/20192018216

2. Guilherme IT, Pimenta F. Meditação mindfulness e esclerose lateral amiotrófica (ELA): uma revisão de literatura. Psicol Saúde Doenças. 2018;19(1):57-63. doi: https://doi.org/10.15309/18psd190109

3. Moura MMD. Família contemporânea e saúde: significados, práticas e políticas públicas [resenha]. Cad Saúde Pública. 2011;27(2):397-8. doi: https://doi. org/10.1590/S0102-311X2011000200023

4. Monteiro GRS, Moraes JCO, Costa SFG, Gomes B MR, França ISX, Oliveira RC. Aplicação do Modelo Calgary de Avaliação Familiar no contexto hospitalar e na atenção primária à saúde: revisão integrativa. Aquichan. 2016;16(4):487-500. doi: https://doi.org/10.5294/aqui.2016.16.4.7

5. Leguia LAS, Montoya-Juarez R, García-Caro MP, López-Morales M, Montalvo A. Experiencia del cuidador familiar con los cuidados paliativos y al final de la vida. Index Enferm. 2019 [cited 2020 Jul 10];28(1-2):51-5. Available from: http://scielo.isciii. es/scielo.php?script=sci_arttext\&pid=\$1132-12962019000100011\&lng=es

6. Cesário VAC, Leal MCC, Marques APO, Claudino KA. Estresse e qualidade de vida do cuidador familiar de idoso portador de Doença de Alzheimer. Saúde Debate. 2017;41(112):171-82. doi: https://doi.org/10.1590/0103-1104201711214

7. Schaepe C, Ewers M. "I see myself as part of the team"- family caregivers' contribution to safety in advanced home care. BMC Nurs. 2018;17:40 doi: https:// doi.org/10.1186/s12912-018-0308-9

8. Schutz VG, Schwartz E, Oliveira SG, Spagnolo LML, Paula EA. Sentimentos dos cuidadores familiares de pacientes adultos hospitalizados: revisão integrativa. Enferm Actual Costa Rica. 2019 [cited 2020 Jul 10];(37):155-67. Available from: https://www.scielo.sa.cr/pdf/enfermeria/n37/1409-4568-enfermeria-37-155.pdf

9. Arrias-Rojas, M, Carreno-Moreno, S, Posada-Lopez, C. Uncertainty in illness in family caregivers of palliative care patients and associated factors. Rev Latino-Am Enfermagem. 2019;27:e3200. doi: https://doi.org/10.1590/1518-8345.3185.3200 
10. Selli L, Vial EA, Junges JR. A enfermagem na ressignificação da vida diante da enfermidade. Rev Bras Enferm. 2005;58(1):82-5. doi: https://doi.org/10.1590/ S0034-71672005000100016

11. Heidegger, M. Ser e tempo. 10a ed. Petrópolis: Vozes; 2015.

12. Costa LPS. Ser cuidador familiar da pessoa com Esclerose Lateral Amiotrófica na perspectiva da fenomenologia existencial [dissertação]. Maceió (AL): Universidade Federal de Alagoas; 2020.

13. Fávero FM, Voos MC, Castro I, Caromano FA, Oliveira ASB. Epidemiological and clinical factors impact on the benefit of riluzole in the survival rates of patients with ALS. Arq Neuro-Psiquiatr. 2017;75(8):515-22. doi: https://doi. org/10.1590/0004-282x20170083

14. Winther D, Lorenzen CK, Dreyer P. Everyday life experiences of close relatives of people with amyotrophic lateral sclerosis receiving home mechanical ventilation - a qualitative study. J Clin Nurs. 2020;29(13-14):2306-16. doi: https://doi. org/10.1111/jocn.15239

15. Scull-Torres M, La observancia de la bioética en el cuidado paliativo de enfermos com esclerosis lateral amiotrófica. Pers Bioét.2019;23(1):111-21. doi: http://doi. org/10.5294/pebi.2019.23.1.7

\section{- Authorship contribution:}

Conceptualization: Isabel Comassetto e Karine Melo Cezar Alves.

Data curation: Lays Pedrosa dos Santos Costa.

Formal analysis: Lays Pedrosa dos Santos Costa.

Investigation: Lays Pedrosa dos Santos Costa.

Methodology: Isabel Comassetto.

Project administration: Isabel Comassetto.

Supervision: Amuzza Aylla Pereira dos Santos e Regina

Maria dos Santos.

Writing-original draft: Guilherme Oliveira de

Albuquerque Malta.

Writing-review \& editing: Isabel Comassetto e Lays

Pedrosa dos Santos Costa.

\section{- Corresponding author:}

Isabel Comassetto

Email: isabelcomassetto@gmail.com
16. Alves DA, Silva LG, Delmondes AG, Lemos ICS, Kerntopf MR, Albuquerque GA. Cuidador de criança com câncer: religiosidade e espiritualidade como mecanismos de enfrentamento. Rev Cuid. 2016;7(2):1318-24. doi: https://doi.org/10.15649/ cuidarte.v7i2.336

17. Terezam R, Reis-Queiroz J, Hoga LAK. The importance of empathy in health and nursing care. Rev Bras Enferm. 2017;70(3):669-70. doi: https://doi. org/10.1590/0034-7167-2016-0032

18. Gibbs LAL, Anderson MI, Simpson GK, Jones KF. Spirituality and resilience among family caregivers of survivors of stroke: a scoping review. NeuroRehabilitation. 2020;46(1):41-52. doi: https://doi.org/10.3233/NRE-192946

19. Freire MEM, Vasconcelos FM, Silva TN, Oliveira KL. Spiritual and religious assistance to cancer patients in the hospital. J Res Fundam Care Online. 2017;9(2):356-62. doi: https://doi.org/10.9789/2175-5361.2017.v9i2.356-362

20. Arrey AE, Bilsen J, Lacor P, Deschepper R. Spirituality/religiosity: a cultural and psychological resource among Sub-Saharan African migrant women with HIV/ AIDS in Belgium. PLoSOne. 2016;11(7):e0159488. doi: https://doi.org/10.1371/ journal.pone.0159488

\section{Associate editor:}

Rosana Maffacciolli

Editor-in-chief:

Received: 08.27.2020

Approved: 11.12 .2020
Maria da Graça Oliveira Crossetti 